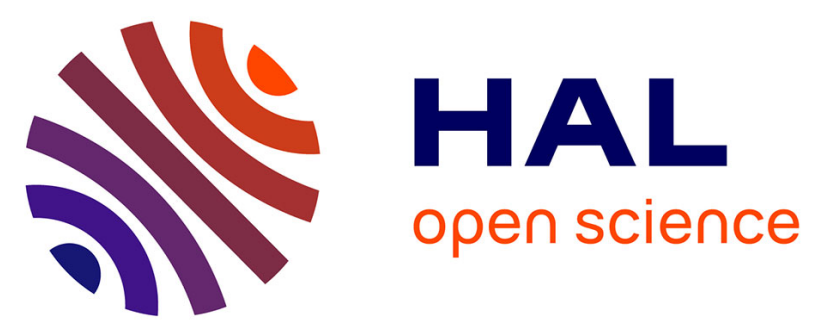

\title{
Involvement of fish immunomarkers in environmental biomonitoring approach: Urban and agri-viticultural context
}

Anne Bado-Nilles, Sabrina Jolly, Florent Lamand, Alain Geffard, Béatrice Gagnaire, Cyril Turies, Jean-Marc Porcher, Wilfried Sanchez, Stéphane

Betoulle

\section{To cite this version:}

Anne Bado-Nilles, Sabrina Jolly, Florent Lamand, Alain Geffard, Béatrice Gagnaire, et al.. Involvement of fish immunomarkers in environmental biomonitoring approach: Urban and agri-viticultural context. Ecotoxicology and Environmental Safety, 2015, 120, pp.35-40. 10.1016/j.ecoenv.2015.05.021 . ineris-01862524

HAL Id: ineris-01862524

https://hal-ineris.archives-ouvertes.fr/ineris-01862524

Submitted on 27 Aug 2018

HAL is a multi-disciplinary open access archive for the deposit and dissemination of scientific research documents, whether they are published or not. The documents may come from teaching and research institutions in France or abroad, or from public or private research centers.
L'archive ouverte pluridisciplinaire HAL, est destinée au dépôt et à la diffusion de documents scientifiques de niveau recherche, publiés ou non, émanant des établissements d'enseignement et de recherche français ou étrangers, des laboratoires publics ou privés. 
Involvement of fish immunomarkers in environmental biomonitoring approach: urban and agri-viticultural context.

\section{Authors}

Anne Bado-Nilles ${ }^{\mathrm{a}, \mathrm{b} *}$, Sabrina Jolly ${ }^{\mathrm{a}, \mathrm{b}}$, Florent Lamand ${ }^{\mathrm{c}}$, Alain Geffard ${ }^{\mathrm{a}}$, Béatrice Gagnaire $^{\mathrm{d}}$, Cyril Turies ${ }^{\mathrm{b}}$, Jean-Marc Porcher ${ }^{\mathrm{b}}$, Wilfried Sanchez ${ }^{\mathrm{b}}$, Stéphane Betoulle

${ }^{a}$ UMR-I 02 (INERIS, URCA, ULH) SEBIO Stress environnementaux et Biosurveillance des milieux aquatiques, Université Reims Champagne-Ardenne (URCA), UFR Sciences Exactes et Naturelles, Moulin de la Housse, B.P. 1039, 51687 Reims, France, sabrina.jolly@univ-reims.fr, $\quad \underline{\text { alain.geffard@univ-reims.fr, }} \quad \underline{\text { stephane.betoulle@,univ- }}$ reims.fr.

b UMR-I 02 SEBIO, Institut National de l'Environnement Industriel et des Risques (INERIS), B.P. 2，60550 Verneuil-en-Halatte, France, anne.bado-nilles@ineris.fr, cyril.turies@,ineris.fr, jean-marc.porcher@ineris.fr, wilfried.sanchez@,ineris.fr.

'Office National de l'Eau et des Milieux Aquatiques (ONEMA), Délégation Inter-Régionale Nord-Est, 57155 Marly, France, florent.lamand@onema.fr. ${ }^{\text {d} I n s t i t u t ~ d e ~ R a d i o p r o t e c t i o n ~ e t ~ d e ~ S u r e t e ́ ~ N u c l e ́ a i r e ~(I R S N), ~ P R P-E N V / S E R I S / L E C O, ~}$ Centre de Cadarache, Bât 186, B.P. 3, 13115 Saint-Paul-lez-Durance, France beatrice.gagnaire@,irsn.fr.

*Corresponding author: anne.bado-nilles@ineris.fr, phone: +33-344-618-121; fax: +33344-556-767. 


\section{Abstract}

The Champagne region (France) is characterized by various chemical environmental pressures which could interfere with the immune status of natural populations of European bullhead, Cottus sp. Some adult fish were caught by electrofishing in spring, summer and autumn to determined immune effect of urban (Muizon), intensive agricultural (Bouy; Prunay) or viticultural (Serzy; Prunay) influences. The major results demonstrated an increase of cellular mortality and a decrease of phagocytosis activity in the stations impacted by agri-viticultural chemicals. These immunomodulations followed the temporal variability due to different treatments (agricultural impacts on spring; viticultural effects on autumn). At the present time, not enough data was provided to confirm the impact of agri-viticultural chemicals on fish immune system without interaction with other environmental factors. For example, in summer, the immunomarkers seems to be not only correlated with water contamination but also with other environmental factors (pathogens, physical field degradation, nutrients, temperature ...). Nevertheless, immune parameters give a global view of organism and ecosystem health explaining growing interest for these biomarkers in environmental risk assessment.

Keywords: Fish; Immunotoxicology; Urban pressure; Agri-viticultural pressures; Biomonitoring; Pathogen. 


\section{Introduction}

The fish immune system is composed of a network of cells capable of rapid proliferation and differentiation, regulated by a variety of soluble factors acting directly on fish health (Bols et al., 2001). Since immune capacities integrate simultaneous over-time contamination by several pollutants (Zelikoff et al., 2000; Van der Oost et al., 2003), chemical disturbance of fish immunity could denote a reduction in pathogen destruction and an increase in fish susceptibility to pathogen aggressions (Reynaud and Deschaux, 2006). So, the ecological relevance of immune parameters by direct implications in individual fitness, population growth, fish and ecosystem health (Bols et al., 2001) explain that these immune parameters are now considered as attractive non-specific markers for environmental risk assessment and biomonitoring programs (Grinwis et al., 2000; Bado-Nilles et al., 2014).

In this context, biomarkers related to innate immune functions are highly relevant due to their non-dependent response of previous exposure to foreign antigens (Monserrat et al., 2007). Cellular mortality may provide the basis to monitor the effect of anthropogenic contaminants since exposure to low concentrations of pollutants could induce apoptosis whereas exposure to severe conditions can result in the injured cells dying due to necrosis (Lyons-Alcantara et al., 1998). Moreover, the induction of cellular mortality could compromise the immune system by disturbance of cellular proliferation and leucocyte differential. In this way, reduction of immune cells could increase disease susceptibility and organism mortality due to immunosuppression. Thus, leucocyte differential and cellular mortality provide the basis to monitor the effect of anthropogenic contaminants due to their high impact on the sanitary status and immune system of fish (Misumi et al., 
2005; Bado-Nilles et al., 2009a; Danion et al., 2011). In another way, phagocytosis, which helps to prevent infectious diseases by non-specific cellular reactions, has also been described as an attractive biomarker of pollution in fish (Reynaud and Deschaux, 2006). Since phagocytosis plays a major role in pathogen defenses in fish (Secombes, 1996; Ellis, 1999), a decrease in its efficiency could contribute to an increased susceptibility to opportunistic infections in animals (Kreutz et al., 2010).

The aim of the present work was to evaluate an environmental biomonitoring approach of ecosystem health, which combined contaminant and pathogen effects, using the capacities of fish immune biomarkers. In this context, immune effects of field multi-contamination due to agri-viticultural and urban environmental pressures were assessed in wild European bullheads, Cottus sp. Since sampling at different season was integrative of chemical treatment evolution variation (Jolly et al., 2012), fish physiological modification and seasonal pattern of infection (Bowden et al., 2007), this study was performed at three periods (spring, summer and autumn). According to its strong sedentary behavior and its ubiquitous distribution in most of European freshwater ecosystems, the European bullhead, Cottus sp., is described as a relevant fish species to assess adverse effects of environmental stress on the health of wild fish in laboratory and field studies (Bucher and Hofer, 1993; Dorts et al., 2011; Jolly et al., 2012). The present paper reports the results of three different fish innate immunomarkers: leucocyte differential, cellular mortality and phagocytosis activity, including phagocytosis efficiency and capacity. All of them were performed by flow cytometry on splenic leucocytes due to the capacities of this organ to filter plasma, trap blood-borne substances and enrich blood on new immune cells (Press and Evensen, 1999). 


\section{Materials and methods}

\section{1. $\quad$ Site descriptions}

Five sites located in the Vesle watershed of the Champagne-Ardennes region were investigated (Fig. 1): Bouy, Prunay and Muizon located on the Vesle River; Courtagnon and Serzy in the tributary Ardre River. These stations have dissimilar chemical water qualities linked to different pressures. Intensive cereal farming and agricultural (sugar beets, alfalfa, peas and potatoes; $70 \%$ of land use) and viticultural practices (5.5\% of land use) influenced the Bouy and Prunay sites, located upstream from the city of Reims (Jolly et al., 2012). Downstream from the city of Reims, Muizon station was an urbanized area location. In the Ardre River, the upstream Courtagnon site was considered as control area due to their forested sector without direct environmental inputs of chemicals, whereas Serzy station, situated downstream, has an intensive wine-growing area pressure. All "poor" water quality stations possess high concentrations of isoproturon, diuron, aminotriazole, glyphosate, atrazine and 2-ethylhexyl ester of 2-methyl-4chlorophenoxyacetic acid (MCPA) in relationship with their intensive agricultural and wine-growing activities (Seine-Normandie Water Agency, 2007).

\subsection{European bullhead collection and tissue sampling}

In each station, 12-20 adult European bullheads were caught by electrofishing in spring (April), summer (July) and autumn (October). No fish was sampling during winter period due to the difficulties to catch this bullheads during this period. For each site, fish were immediately killed by cervical dislocation, weighed, measured, sexed and dissected. Thus, as described by Janssen et al. (1995), the condition factor was calculated as [100 x 
body weight $(\mathrm{g})] /$ length $\left.{ }^{3}(\mathrm{~cm})\right]$. In a second time, gonads were weighed to determine gonado-somatic index (GSI) (Lofts et al., 1966) as $[100 \mathrm{x}$ organ wet weight (g)]/total body weight $(\mathrm{g})$ ]. Spleen tissues were removed to measure immunological parameters.

\subsection{Leucocyte isolation and innate immune biomarkers analysis}

The spleen tissues were pressed through sterilized nylon mesh $(40 \mu \mathrm{m}$, Dutscher $)$ with Leibovitz 15 (L15) medium (Sigma) containing heparin lithium (10 U.mL ${ }^{-1}$, Sigma), penicillin (500 U.mL ${ }^{-1}$, Biochrom AG) and streptomycin $\left(500 \mu \mathrm{g} \cdot \mathrm{mL}^{-1}\right.$, Biochrom AG) to obtain leucocyte suspension. After storage of 12 hours at $4 \pm 1{ }^{\circ} \mathrm{C}, \mathrm{L} 15$ medium-diluted samples were loaded onto Ficoll gradient (Histopaque ${ }^{\circledR} 1077$, density of $1,077 \mathrm{~g} \cdot \mathrm{mL}^{-1}$, Sigma). After centrifugation (400 g, $\left.30 \mathrm{~min}, 15^{\circ} \mathrm{C}\right)$, leucocytes enriched suspensions were collected and washed twice in L15 medium $\left(300 \mathrm{~g}, 5 \mathrm{~min}, 4{ }^{\circ} \mathrm{C}\right)$. Then, leucocytes were adjusted at $10^{6}$ cells. $\mathrm{mL}^{-1}$ with Malassez haemocytometer to perform cytometer analyses.

Analyses were carried out on whole leucocytes, using a Cyan ${ }^{\mathrm{TM}}$ ADP flow cytometer (Beckman Coulter). For each leucocyte sample, 10,000 cells were counted. Leucocyte differential was obtained using forward scatter (FSC) and size scatter (SSC) parameters for size and granularity, respectively. The cellular mortality percentage and the phagocytosis activity were determined, using propidium iodure (1.0 g. $\mathrm{L}^{-1}$, Molecular Probes) and Fluorescent microsphere $\left(2.7 * 10^{10}\right.$ particles.mL $\mathrm{m}^{-1}$, Fluorospheress carboxylatemodified microsphere, diameter $1 \mathrm{~mm}$, Molecular Probes), respectively, according to Bado-Nilles et al. (2009a). 


\subsection{Statistical analysis}

Results were expressed as means \pm standard error. Verification of normality and of homogeneity of covariance matrices were conducted using respectively the Anderson-Darling test and the Bartlett test on XLStat 2008 (Addinsoft). Since the values were not normally distributed, the data was converted into $r$ angular arcsinus $\sqrt{ }(\%$ of positive cells) before analysis. A two-way analysis of variance (ANOVA) was used to compare the effect for each season of each field station on immune parameters. The effects and possible interactions of season, sex and morphometric indices in explaining variation on immune parameters were analyzed using multi-factor analysis of covariance (ANCOVAs) based on Fisher's F test. The Student Newman-Keuls's test was used for all multiple comparisons. All hypotheses were tested for statistical significance at the level of $\mathrm{p} \leq 0.05$. 


\section{Results}

\subsection{Effects of season, fish morphometric indices and sex on immune responses}

In April no significant differences were recorded among investigated sites with

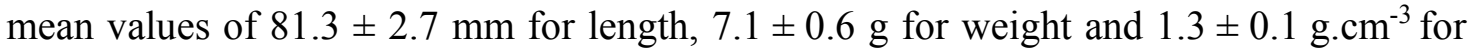
condition factor (data not shown). In October, Courtagnon's fish possessed a weak length $(73.1 \pm 2.7 \mathrm{~mm})$ and weight $(5.1 \pm 0.7 \mathrm{~g})$ compared to other sites (mean of $83.8 \pm 2.2 \mathrm{~mm}$ and of $7.4 \pm 0.6 \mathrm{~g})$ without differences in condition factor $\left(1.2 \pm 0.1 \mathrm{~g} . \mathrm{cm}^{-3}\right.$, data not shown). Regardless to the two others sampling date, fish caught in July shown an important modification of their morphometric indices between stations (data not shown). The length was lower in fish from Courtagnon and Serzy stations compared to others. Fish from each station had a rather dissimilar weight and condition factor with lower values in Courtagnon $\left(4.8 \pm 0.5 \mathrm{~g}, 1.2 \pm 0.1 \mathrm{~g} . \mathrm{cm}^{-3}\right)$ and bigger data in Muizon $\left(11.7 \pm 1.2 \mathrm{~g}, 1.6 \pm 0.2 \mathrm{~g} . \mathrm{cm}^{-3}\right)$. Modification of these morphometric indices have no significant impact on immune parameters tested regardless of season (Table 1).

In the same way, sex had no significant impact on the present immune parameters regardless of season (Table 1), even if female fish $(1.3 \pm 0.1 \%$ in April; $0.8 \pm 0.1 \%$ in July; $1.7 \pm 0.1 \%$ in October; data not shown) possess high GSI compared to male $(0.5 \pm 0.1 \%$ in April; $0.1 \pm 0.1 \%$ in July; $1.4 \pm 0.1 \%$ in October; data not shown $)$ and GSI data were lower in July than in April and October. Furthermore, little impact on GSI was detected between stations: in April females coming from Serzy $(1.4 \pm 0.1 \%)$ and Prunay $(1.7 \pm 0.1 \%)$ have higher values compared to others $(1.2 \pm 0.1 \%)$; in October male and female data were lower in Vesle $(1.1 \pm 0.1 \%$ for male; $1.5 \pm 0.1 \%$ for female $)$ than Ardre River $(1.8 \pm 0.1 \%$ for male; $2.1 \pm 0.1 \%$ for female $)$. 
In spite of the absence of impact of morphometric index and sex on immune parameter tested, seasonal variation induced important modification of leucocyte differential $\left(\mathrm{R}^{2}=0.714, \mathrm{p}<0.0001\right)$ and cellular mortality $\left(\mathrm{R}^{2}=0.720, \mathrm{p}<0.0001\right)$ without impact on phagocytosis capacity $\left(\mathrm{R}^{2}=0.170, \mathrm{p}=0.001\right)$ and efficiency $\left(\mathrm{R}^{2}=0.215, \mathrm{p}=0.022\right)$ (Table 1). Concerning leucocyte differential, except for station variation, spring and summer presented values around $70-75 \%$ of lymphocytes whereas autumn presented an important destabilization of the leucocyte population with approximately $35 \%$ of lymphocyte regardless of the site (Fig. 2). The cellular mortality was rather similar along the year for Courtagnon (mean of $3.8 \pm 0.4 \%$ ) and Muizon (mean of $4.2 \pm 0.4 \%$ ) stations. In contrary, Bouy $(17.7 \pm 5.1 \%$ ) and Prunay $(12.5 \pm 1.7 \%)$ had bigger values in spring and Serzy in spring $(13.3 \pm 3.9 \%)$ and autumn $(13.6 \pm 1.1 \%)$ too (Fig. 2).

\subsection{Pressure effects on innate immune responses}

The control station, Courtagnon, shown very stable immune parameters along the year with lower cellular mortality (mean of $3.8 \pm 0.4 \%$ ) and higher phagocytosis capacity (mean of $64.4 \pm 3.2 \%$ ) and efficiency (mean of $47.2 \pm 3.3 \%$ ) compared to all others stations. Nevertheless, leucocyte differential varied among season: $68.1 \pm 2.5 \%$ of lymphocytes in spring; $85.1 \pm 2.0 \%$ of lymphocytes in summer; $32.3 \pm 2.3 \%$ of lymphocytes in autumn (Fig. 2).

Immune system of fish caught at Muizon, which have an urban pressure, was weakly impacted. In spring, only this site possessed a destabilization of their leucocyte differential $(54.8 \pm 3.2 \%$ of lymphocytes) compared to others (mean of $73.0 \pm 2.9 \%$ of 
lymphocytes). In summer $(88.5 \pm 3.2 \%$ of lymphocytes $)$ and autumn $(31.7 \pm 3.0 \%$ of lymphocytes) values were comparable to these from Courtagnon reference site $(85.1 \pm 2.0 \%$ of lymphocytes in summer; $32.3 \pm 2.3 \%$ of lymphocytes in autumn). The leucocyte mortality did not vary along the year (mean of $4.2 \pm 0.4 \%$ ) and was similar to Courtagnon percentage (mean of $3.8 \pm 0.4 \%$ ). Phagocytosis efficiency (mean of $37.6 \pm 2.0 \%$ ) and capacity (mean of $55.6 \pm 2.4 \%$ ) were not significantly modified along the year and were similar to control data (mean of $47.2 \pm 3.3 \%$ for phagocytosis efficiency; mean of $64.4 \pm 3.2 \%$ for phagocytosis capacity) (Fig. 2).

The more important immune modulation along the year was due to agri-viticultural practices. Compared to control $(68.1 \pm 2.5 \%$ of lymphocytes in spring; $85.1 \pm 2.0 \%$ of lymphocytes in summer; $32.3 \pm 2.3 \%$ of lymphocytes in autumn), Prunay showed dissimilar leucocyte differential along the year $(80.1 \pm 2.1 \%$ of lymphocytes in spring; $72.6 \pm 2.9 \%$ of lymphocytes in summer; $55.5 \pm 1.6 \%$ of lymphocytes in autumn) whereas Bouy presented only variations in summer $(65.7 \pm 2.9 \%$ of lymphocytes $)$ and Serzy was always similar $(70.8 \pm 3.6 \%$ of lymphocytes in spring; $88.1 \pm 1.4 \%$ of lymphocytes in summer; $25.4 \pm 2.2 \%$ of lymphocytes in autumn). Moreover, in spring, these three stations $(13.3 \pm 5.1 \%$ for Serzy, $12.5 \pm 1.7 \%$ for Prunay, $17.7 \pm 5.1 \%$ for Bouy) presented an increase of their leucocyte mortalities compared to other sites (mean of $5.5 \pm 0.1 \%$ ). In summer, values were similar regardless to the station. In opposite, an important leucocyte mortality was detected in autumn at Serzy $(13.6 \pm 1.1 \%)$, then Prunay $(7.6 \pm 0.7 \%)$ and finally the three other sites (mean of $4.9 \pm 0.4 \%$ ). Concerning spring phagocytosis activity, compared to Courtagnon $(49.1 \pm 3.0 \%$ of phagocytosis efficiency; $67.0 \pm 2.7 \%$ of 
phagocytosis capacity), the intensive cereal farming and agricultural practices induced a more important decrease of phagocytosis efficiency $(26.0 \pm 1.9 \%$ for Prunay, $21.2 \pm 1.1 \%$ for Bouy $)$ and capacity $(43.4 \pm 1.5 \%$ for Prunay, $41.2 \pm 2.0 \%$ for Bouy $)$ then only wine-growing activities (Serzy: $38.2 \pm 3.8 \%$ of phagocytosis efficiency; $57.8 \pm 3.8 \%$ of phagocytosis capacity) or urban pressures (Muizon: $40.7 \pm 2.2 \%$ of phagocytosis efficiency; $55.9 \pm 2.6 \%$ of phagocytosis capacity). In summer, phagocytosis efficiency and capacity stayed lower in Serzy $(33.8 \pm 2.7 \%$ and $52.4 \pm 2.7 \%$, respectively) and Bouy $(25.0 \pm 0.9 \%$ and $47.1 \pm 3.0 \%$, respectively) compared to reference site $(47.6 \pm 4.6 \%$ and $64.0 \pm 4.0 \%$, respectively). In autumn, only Prunay $(31.4 \pm 2.9 \%)$ present a lower phagocytosis efficiency compared to Serzy-Muizon (mean of $39.3 \pm 2.1 \%$ ) and mostly to Bouy-Courtagnon (mean of $48.9 \pm 3.1 \%$ ) with no impact on phagocytosis capacity (Fig. 2). 


\section{Discussion}

In the present time, only few studies have used components of the immune system for environmental risk assessment purposes (Grinwis et al., 2000; Bado-Nilles et al., 2014), though a number of environmental chemicals can impair them (Anderson and Brubacher, 1993; Carlson et al., 2004; Bado-Nilles et al., 2009b). Due to their direct implications in individual fitness and population growth, these immunomarkers give some attractive information on global ecosystem health due to different anthropic pressures.

As reviewed by Zia et al. (2013), degradation of freshwater quality, by chemical and nutrient fluxes, is mainly attributed to outdated farm management practices including excessive use of fertilizers, pesticides and herbicides. In the present study, while immune modulation due to urban contamination was poorly observed, agri-viticultural treatments induce major impacts on immune parameters. Moreover, agri-viticultural treatments exhibit also strong temporal variability which must not be neglected for determination of environmental risk assessment (Jolly et al., 2012). In fact, major impacts on immune parameters of agricultural practices were shown on spring, whereas viticultural effects were particularly detected in autumn. These results were certainly due to difference in specific prophylactic treatments by pesticides and herbicides, which are known to modulate immune parameters in fish (Dunier and Siwicki, 1993). Nevertheless, relationship between each environmental factor and immune parameters must not be neglect in field context. 
In spring, area impacted by agriculture showed a decrease of phagocytosis activity and an increase of cellular mortality without leucocyte differential destabilization. This immune response could be induced by the use of many pesticides and/or herbicides during prophylactic treatments and detected in the Vesle watershed (Seine-Normandie Water Agency, 2007). For example, after 96 hours of exposure of silver catfish (Rhamdia quelen) to sublethal concentrations of glyphosate, Kreutz et al. (2011) suggested that the reduction of leucocytes was offset by important increase in the number of immature circulating cells. This leucocyte turn-over could explain the important increase of cellular mortality in agricultural sites without modification of leucocyte differential. Nonetheless, the reduction of leucocyte population could disturb natural immune function such as phagocytosis capacity. In fact, both glyphosate and atrazine caused a significant reduction on phagocytic index after 24 hours of contamination (Kreutz et al., 2010). The ability to phagocyte antigens could be reduced by damage to cell membrane and by lack of their fluidity (Gauvrit, 1984; Blasiak, 1995; Gabbianelli et al., 2002; Kreutz et al., 2010), which come from an increase of oxidative stress (Kreutz et al., 2010) and a decrease of glutathione peroxidase activity (Gabbianelli et al., 2002). In accordance, previous study on Vesle watershed shown, in agricultural stations, an increase of oxidative stress demonstrated by enhancement of glutathione-S-transferase and reduction of glutathione peroxidase (Jolly et al., 2012). These biochemical modifications could explain the modification of leucocyte membrane fluidity and thus the reduction of phagocytosis activity. Moreover, atrazine, one of the most agricultural pesticide detected in the Vesle watershed (Seine-Normandie Water Agency, 2007), is known to compromise the phagocytosis ability of leucocytes by alteration of receptor expression needed for antigen 
identification, or the production of stimulating cytokines and proteins from the phagocytic pathway (Pinchuk et al., 2007; McCarthy and Fuiman, 2008).

In autumn, whereas immune effect was totally reversed in Bouy station, the vineyard areas (Prunay and Serzy) were still impacted. Diuron was the major viticultural pesticide detected in the Vesle watershed (Seine-Normandie Water Agency, 2007) and copper was specifically used in autumn to control fungal diseases in vineyards (Teisseire, 1999; Dautremepuits et al., 2004). As previously observed with agricultural pressures, an increase of cellular mortality was detected. As many pesticides, diuron and copper may generate reactive oxygen species (ROS) and induce an overwhelming of the antioxidant system (Dautremepuits et al., 2004; Luna-Acosta et al., 2012). This oxidative stress could be accountable to reduction of cellular viability by increasing DNA strand breaks leading to apoptosis (Bopp et al., 2008) or decreasing functional integrity of the lysosomal membrane (Roméo et al., 2000; Krumschnabel et al., 2005) inducing necrosis by release of acid hydrolases (Holtzman, 1989). As discussed above, increase of cellular mortality could induce the observed impairment of phagocytosis capacity. The mechanism involved in phagocytosis reduction has not been investigated yet; nevertheless we could suppose that mechanism was similar to that shown in spring with agricultural pesticides.

In summer, Bouy and Prunay samplings had an important destabilization of leucocyte differential. The absence of cellular mortality rise suggested an important increase of granulocytes-macrophages sub-populations to restrict the lower phagocytosis capacity induce by agrichemicals as discussed above. In fact, a reduction of efficiency of phagocytosis capacity could contribute to an increased susceptibility to opportunistic infections in animals. For instance, Kreutz et al. (2010) demonstrated that the presence of 
glyphosate or atrazine, two agricultural herbicides detected in the Vesle watershed (Seine-Normandie Water Agency, 2007), altered the macrophage phagocytic activity of silver catfish fingerlings (Rhamdia quelen) and increased their susceptibility to Aeromonas hydrophila challenge. In the same manner, Danion et al. (2012) shown that chronic pollution by pendimethalin, a dinitroaniline herbicide, accelerating death in rainbow trout, Oncorhynchus mykiss, infected by viral hemorrhagic septicemia virus and increase concentration of viral particles in hematopoietic organs. A temporary impairment of immune responses, such as lower phagocytic activity and leucopenia, could explain these results (Danion et al., 2012). Since natural environment of fish presents many pathogens which could disturb animal's health, the particular immune profile detected in Bouy and Prunay stations could be due to a compensatory strategy developed by organism in presence of pathogens to minimize pollutant immunosuppressive effect. This hypothesis was supported by the works of Nacci et al. (2009) who reported an evolution of PCB immunosuppressive effects to a population of Atlantic killifish, Fundulus heteroclitus, within pathogen infection. Moreover, the presence of pathogens seems to be supported by previous work where an enhancement of lysozyme concentration was detected in the same sites (Jolly et al., 2012). The fish immune response could be modified by many environmental factors (chemicals, pathogens, physical field degradation, nutrients, temperature...). At term, the disturbance of this fundamental physiological function could induce drastic population effects, for example during combined pathogen-pollutant stress (Danion et al., 2012). This overall view of ecosystem health (pollutant, host, pathogen) explained that we recommended to integrate immunomarkers in environmental risk assessment. 


\section{Conclusions}

High sensitivity of immune system was demonstrated by great detection along the year of agricultural and viticultural pressures in spite of seasonal immune variations. Nonetheless immune modifications followed the temporal variability due to different treatments with major agricultural impacts on spring and viticultural effects on autumn. In accordance with Jolly et al. (2012), biomarker deployment required a design of freshwater risk assessment studies based on variability of environmental pressures. Notwithstanding, use of immunomarkers gives not only information on chemical water qualities but also on biological contaminations. In fact, obtained results can be significantly affected by pathogen load. In this way, the determination of pathogen infection period and pathogenic profile of fish were also attractive for use of immunomarkers in environmental risk assessment. In fact, major risk of fish mortality appears to be in the presence of contaminants and pathogens. In this way, the analysis of immunomarkers should be preferentially performed during combined chemical treatment and fish infection. In biomonitoring context, it could be very difficult to field this perfect pollutant-host-pathogen scheme. For this reason, some interesting additional research will be needed to obtain threshold values of immunomarkers to better assess fish health effect irrespective of pathogen seasonality. 


\section{Acknowledgement}

This work was funded by the French Ministry of Ecology and Sustainable Development (Programme 190 Ecotoxicology and Programme 190 post grenelle DEVIL). This project was also supported the European Regional Development Fund in the framework of the INTERREG IV A France (Channel) - England program (DIESE project). During this project, all experiments were conducted in accordance with the Commission recommendation 2007/526/EC on revised guidelines for the accommodation and care of animals used for experimental and other scientific purposes. 


\section{References}

Anderson, R. S. \& Brubacher, L. L., 1993. Inhibition by pentachlorophenol of production of reactiveoxygen intermediates by medaka phagocytic blood cells. Marine Environmental Research 35(1-2), 125 129.

Bado-Nilles, A. Quentel, C. Auffret, M. Le Floch, S. Renault, T. \& Thomas-Guyon, H., 2009a. Immune effects of HFO on European sea bass, Dicentrarchus labrax, and Pacific oyster, Crassostrea gigas. Ecotoxicology and Environmental Safety 72(5), 1446-1454.

Bado-Nilles, A. Quentel, C. Thomas-Guyon, H. \& Le Floch, S., 2009b. Effects of two oils and 16 pure polycyclic aromatic hydrocarbons on plasmatic immune parameters in the European sea bass, Dicentrarchus labrax (Linné). Toxicology in Vitro 23(2), 235-241.

Bado-Nilles, A. Jolly, S. Porcher, J.-M. Palluel, O. Geffard, A. Gagnaire, B. Betoulle, S. \& Sanchez, W., 2014. Applications in environmental risk assessment of leucocyte apoptosis, necrosis and respiratory burst analysis on European bullhead, Cottus sp. Environmental Pollution 184, 9-17.

Blasiak, J., 1995. Changes in membrane fluidity evoked by organophosphorus insecticide bromfenvinfos and its methylated analogue. Comparative Biochemistry and Physiology Part C: Pharmacology, Toxicology and Endocrinology 110(1), 15-21.

Bols, N. C. Brubacher, J. L. Ganassin, R. C. \& Lee, L. E. J., 2001. Ecotoxicology and innate immunity in fish. Developmental \& Comparative Immunology 25(8-9), 853-873.

Bopp, S. K. Abicht, H. K. \& Knauer, K., 2008. Copper-induced oxidative stress in rainbow trout gill cells. Aquatic Toxicology 86(2), 197-204.

Bowden, T. J. Thompson, K. D. Morgan, A. L. Gratacap, R. M. L. \& Nikoskelainen, S., 2007. Seasonal variation and the immune response: A fish perspective. Fish \& Shellfish Immunology 22(6), 695-706.

Bucher, F. \& Hofer, R., 1993. Histological and enzyme histochemical changes in the kidney of male bullhead (Cottus gobio) during the spawning period. Journal of Fish Biology 42(3), 403-409.

Carlson, E. A. Li, Y. \& Zelikoff, J. T., 2004. Suppressive effects of benzo[a]pyrene upon fish immune function: evolutionarily conserved cellular mechanisms of immunotoxicity. Marine Environmental Research 58(2-5), 731-734. 
Danion, M. Le Floch, S. Kanan, R. Lamour, F. \& Quentel, C., 2011. Effects of in vivo chronic hydrocarbons pollution on sanitary status and immune system in sea bass (Dicentrarchus labrax L.). Aquatic Toxicology 105(3-4), 300-311.

Danion, M. Le Floch, S. Castric, J. Lamour, F. Cabon, J. \& Quentel, C., 2012. Effect of chronic exposure to pendimethalin on the susceptibility of rainbow trout, Oncorhynchus mykiss L., to viral hemorrhagic septicemia virus (VHSV). Ecotoxicology and Environmental Safety 79, 28-34.

Dautremepuits, C. Betoulle, S. Paris-Palacios, S. \& Vernet, G., 2004. Immunology-Related Perturbations Induced by Copper and Chitosan in Carp (Cyprinus carpio L.). Archives of Environmental Contamination and Toxicology 47(3), 370-378.

Dorts, J. Kestemont, P. Marchand, P. A. D'Hollander, W. Thezenas, M. L. Raes, M. \& Silvestre, F., 2011. Ecotoxicoproteomics in gills of the sentinel fish species, Cottus gobio, exposed to perfluorooctane sulfonate (PFOS). Aquatic Toxicology 103(1-2), 1-8.

Dunier, M. \& Siwicki, A. K., 1993. Effects of pesticides and other organic pollutants in the aquatic environment on immunity of fish: a review. Fish \& Shellfish Immunology 3(6), 423-438.

Ellis, A. E., 1999. Immunity to bacteria in fish. Fish \& Shellfish Immunology 9(4), 291-308.

Gabbianelli, R. Falcioni, G. Nasuti, C. \& Cantalamessa, F., 2002. Cypermethrin-induced plasma membrane perturbation on erythrocytes from rats: reduction of fluidity in the hydrophobic core and in glutathione peroxidase activity. Toxicology 175(1-3), 91-101.

Gauvrit, C., 1984. Effects of the herbicides benzoylpropethyl and flampropisopropyl on rat liver mitochondria: An alteration in membrane fluidity? Pesticide Biochemistry and Physiology 21(3), $377-$ 384.

Grinwis, G. C. M. Vethaak, A. D. Wester, P. W. \& Vos, J. G., 2000. Toxicology of environmental chemicals in the flounder (Platichthys flesus) with emphasis on the immune system: field, semi-field (mesocosm) and laboratory studies. Toxicology Letters 112-113, 289-301.

Holtzman, E., 1989. Lysosomes. New York, Plenum Press. pp. 445

Janssen, P. A. H. Lambert, J. G. D. \& Goos, H. J. T., 1995. The Annual Ovarian Cycle and the Influence of Pollution on Vitellogenesis in the Flounder, Pleuronectes Flesus. J. Fish Biol. 47(3), 509-523. 
Jolly, S. Bado-Nilles, A. Lamand, F. Turies, C. Chadili, E. Porcher, J.-M. Betoulle, S. \& Sanchez, W., 2012. Multi-biomarker approach in wild European bullhead, Cottus sp., exposed to agricultural and urban environmental pressures: practical recommendations for experimental design. Chemosphere $87(7), 675-683$.

Kreutz, L. C. Gil Barcellos, L. J. Marteninghe, A. Davi dos Santos, E. \& Zanatta, R., 2010. Exposure to sublethal concentration of glyphosate or atrazine-based herbicides alters the phagocytic function and increases the susceptibility of silver catfish fingerlings (Rhamdia quelen) to Aeromonas hydrophila challenge. Fish \& Shellfish Immunology 29(4), 694-697.

Kreutz, L. C. Gil Barcellos, L. J. de Faria Valle, S. de Oliveira Silva, T. Anziliero, D. Davi dos Santos, E. Pivato, M. \& Zanatta, R., 2011. Altered hematological and immunological parameters in silver catfish (Rhamdia quelen) following short term exposure to sublethal concentration of glyphosate. Fish \& Shellfish Immunology 30(1), 51-57.

Krumschnabel, G. Manzl, C. Berger, C. \& Hofer, B., 2005. Oxidative stress, mitochondrial permeability transition, and cell death in $\mathrm{Cu}$-exposed trout hepatocytes. Toxicology and Applied Pharmacology 209(1), 62-73.

Lofts, B. Pickford, G. E. \& Atz, J. W., 1966. Effects of methyl testosterone on the testes of a hypophysectomized cyprinodont fish, Fundulus heteroclitus. General and Comparative Endocrinology 6(1), 74-88.

Luna-Acosta, A. Renault, T. Thomas-Guyon, H. Faury, N. Saulnier, D. Budzinski, H. Le Menach, K. Pardon, P. Fruitier-Arnaudin, I. \& Bustamante, P., 2012. Detection of early effects of a single herbicide (diuron) and a mix of herbicides and pharmaceuticals (diuron, isoproturon, ibuprofen) on immunological parameters of Pacific oyster (Crassostrea gigas) spat. Chemosphere 87(11), 1335-1340.

McCarthy, I. D. \& Fuiman, L. A., 2008. Growth and protein metabolism in red drum (Sciaenops ocellatus) larvae exposed to environmental levels of atrazine and malathion. Aquatic Toxicology 88(4), 220-229.

Misumi, I. Vella, A. T. Leong, J.-A. C. Nakanishi, T. \& Schreck, C. B., 2005. p,p'-DDE depresses the immune competence of chinook salmon (Oncorhynchus tshawytscha) leukocytes. Fish \& Shellfish Immunology 19(2), 97-114. 
Monserrat, J. M. Martinez, P. E. Geracitano, L. A. Lund Amado, L. Martinez Gaspar Martins, C. Lopes Leaes Pinho, G. Soares Chaves, I. Ferreira-Cravo, M. Ventura-Lima, J. \& Bianchini, A., 2007. Pollution biomarkers in estuarine animals: Critical review and new perspectives. Comparative Biochemistry and Physiology - Part C 146(1-2), 221-34.

Nacci, D. Huber, M. Champlin, D. Jayaraman, S. Cohen, S. Gauger, E. Fong, A. \& Gomez-Chiarri, M., 2009. Evolution of tolerance to PCBs and susceptibility to a bacterial pathogen (Vibrio harveyi) in Atlantic killifish (Fundulus heteroclitus) from New Bedford (MA, USA) harbor. Environmental Pollution 157(3), 857-864.

Pinchuk, L. M. Lee, S.-R. \& Filipov, N. M., 2007. In vitro atrazine exposure affects the phenotypic and functional maturation of dendritic cells. Toxicology and Applied Pharmacology 223(3), 206-217.

Press, C. M. \& Evensen, Ø., 1999. The morphology of the immune system in teleost fishes. Fish \& Shellfish Immunology 9(4), 309-318.

Reynaud, S. \& Deschaux, P., 2006. The effects of polycyclic aromatic hydrocarbons on the immune system of fish: a review. Aquatic Toxicology 77(2), 229-238.

Roméo, M. Bennani, N. Gnassia-Barelli, M. Lafaurie, M. \& Girard, J. P., 2000. Cadmium and copper display different responses towards oxidative stress in the kidney of the sea bass Dicentrarchus labrax. Aquatic Toxicology 48(2-3), 185-194.

Secombes, C. J., 1996. The nonspecific immune system: cellular defenses in The fish immune system: organism, pathogen, and environment. Eds: G. Iwana and T. Nakanishi. San Diego, California, Harcourt Brace \& Company. pp. 63 - 103.

Seine-Normandie Water Agency, 2007. Aisne Vesle Suippe. $<$ http://www.eau-seinenormandie.fr/fileadmin/mediatheque/valleesdoise/ComGeo/ComGeo_2007 Mars/FICHES/Fiches_Eaux_SUP/EAUX_SUP_AISNE_V_S.pdf $>$.

Teisseire, H., 1999. Toxicologie et écotoxicologie des pesticides et des métaux lourds susceptibles d'être présents dans le vignoble champenois : étude de leur impact physiologique et biochimique sur Lemna minor. Université de Reims Champagne-Ardenne, Reims, France, 272.

Van der Oost, R. Beyer, J. \& Vermeulen, N. P. E., 2003. Fish bioaccumulation and biomarkers in environmental risk assessment: a review. Environmental Toxicology and Pharmacology 13(2), 57-149. 
Zelikoff, J. T. Raymond, A. Carlson, E. Li, Y. Beaman, J. R. \& Anderson, M., 2000. Biomarkers of immunotoxicity in fish: from the lab to the ocean. Toxicology Letters 112-113, 325-331.

Zia, H. Harris, N. R. Merrett, G. V. Rivers, M. \& Coles, N., 2013. The impact of agricultural activities on water quality: A case for collaborative catchment-scale management using integrated wireless sensor networks. Computers and Electronics in Agriculture 96, 126-138. 
Table 1: Possible interactions of season, sex and morphometric indices on immunological variations were monitored from European bullhead (Cottus sp.) collected in each site. These tests were made using multi-factor analysis of covariance (ANCOVAs) based on Fisher's F test, with significant F value when data are lower than 0.0005. Values corresponded to $i$ ) the coefficient of determination of the model $\left(\mathrm{R}^{2}\right)$ which indicates the quantity of dependant variable explain by season, sex and morphometric indices; and to ii) the $\mathrm{F}$ values from quantitative explanatory variables which are computed by removing one variable of the model at a time to evaluate its impact on the quality of the model.

\begin{tabular}{cccccccc}
\hline & & \multicolumn{5}{c}{ Quantitative explanatory variables (Fisher's F test) } \\
\cline { 3 - 8 } Quantitative dependant variable & $\mathrm{R}^{2}$ & Season & Sex & Length (cm) & Weight (g) & Condition factor & GSI \\
\hline Leucocyte differential & 0.714 & $<\mathbf{0 . 0 0 0 1}$ & 0.574 & 0.115 & 0.958 & 0.213 & 0.737 \\
Cellular mortality & 0.720 & $<\mathbf{0 . 0 0 0 1}$ & 0.807 & 0.305 & 0.722 & 0.672 & 0.106 \\
Phagocytosis efficiency & 0.215 & 0.022 & 0.920 & 0.120 & 0.031 & 0.406 & 0.953 \\
Phagocytosis capacity & 0.170 & 0.001 & 0.493 & 0.094 & 0.480 & 0.443 & 0.623 \\
\hline
\end{tabular}


Fig. 1: Sampling sites on Vesle river system, with (A) localization of sites in France and (B) localization of the selected sampling sites in Vesle basin with identification of environmental pressures.

Fig. 2: Immunological biomarkers (leucocyte differential, cellular mortality and phagocytosis efficiency and capacity) monitored from European bullhead (Cottus sp.) collected during three seasons (spring; summer; autumn) in each site. Values are means \pm standard error of 12-20 fish by site. For each parameter, difference between rivers and season was indicated by different letters for $\mathrm{p} \leq 0.05$ with $\mathrm{a}>\mathrm{b}>\mathrm{c}>\mathrm{d}>\mathrm{e}>\mathrm{f}>\mathrm{g}$. 
Fig. 1

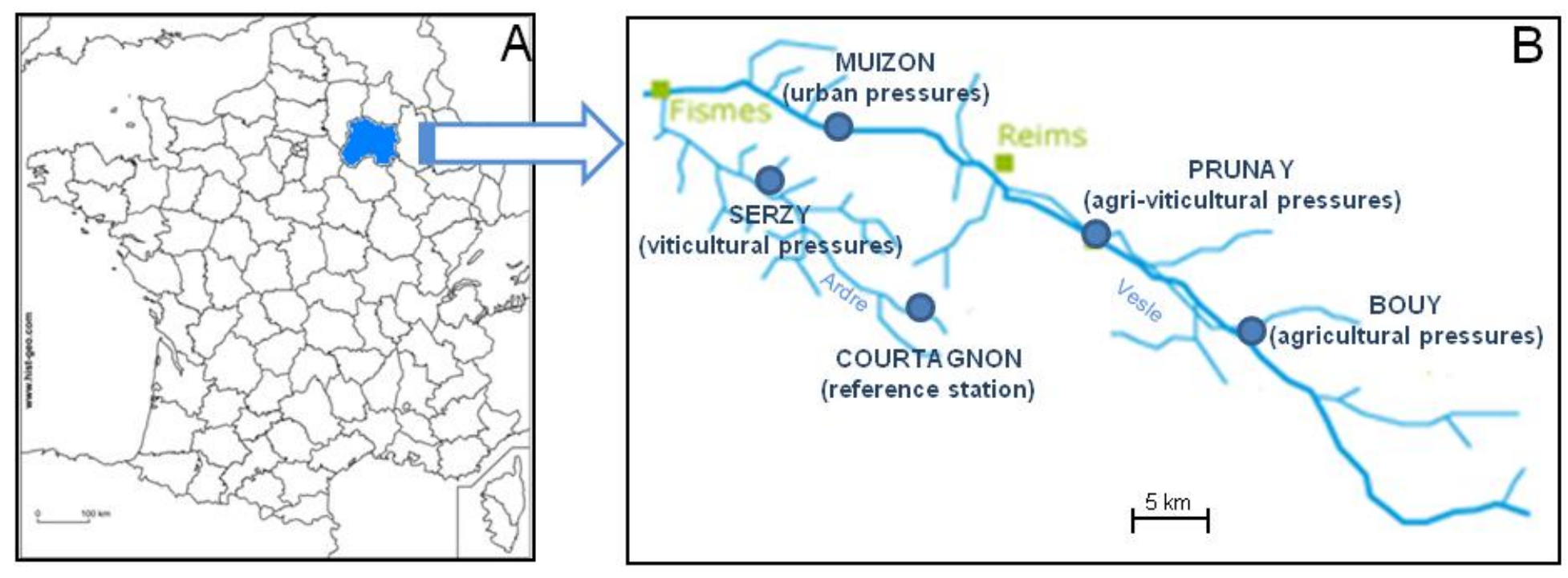


Fig. 2
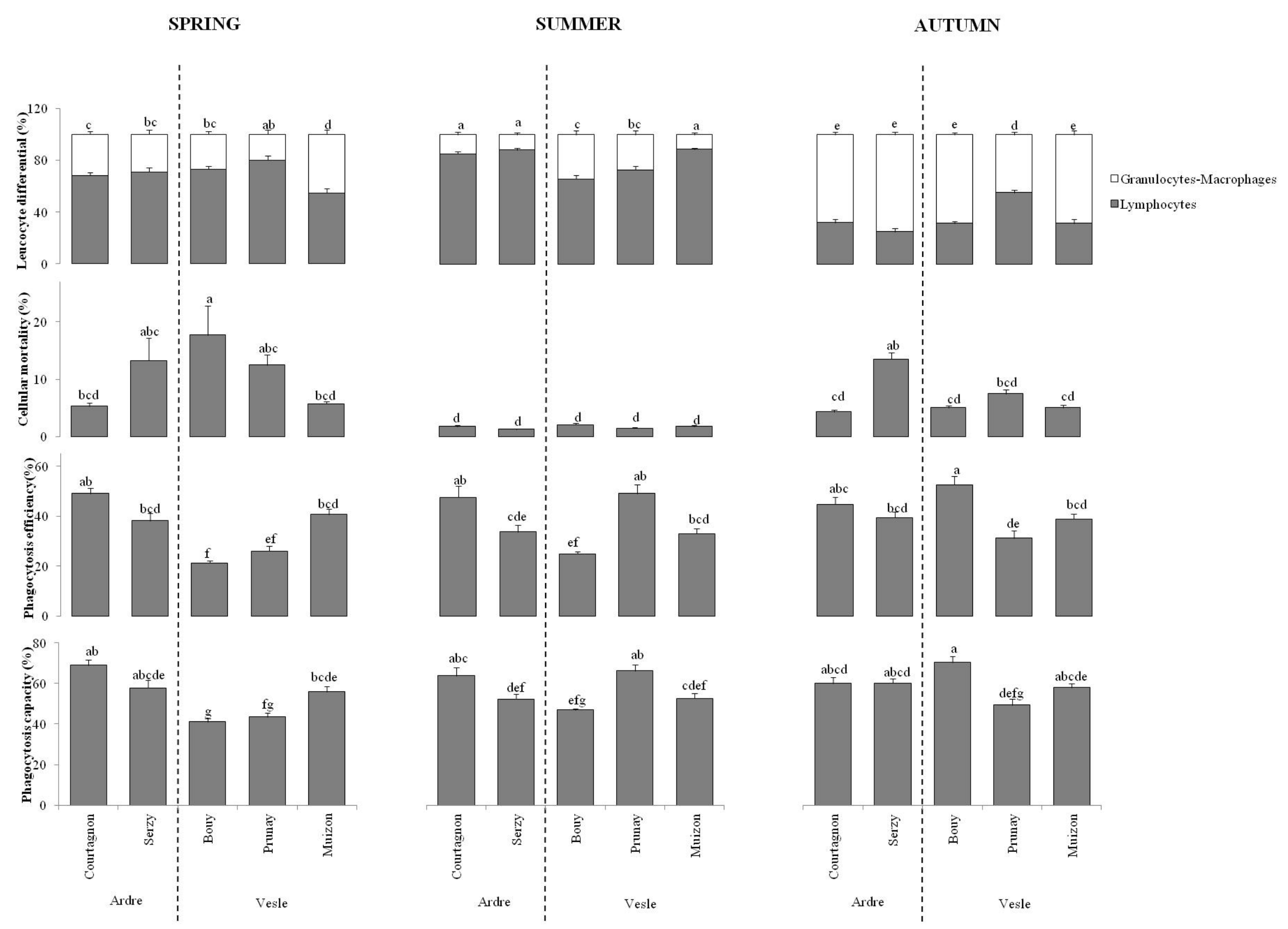